\title{
THERMAL PERFORMANCE OF AN EXPERIMENTAL CAR-TIRE SOLAR COOKER
}

\author{
Hanan, M. S. El-Shal*
}

ABSTRACT

The aim of this study is evaluating the thermal performance of a simple and inexpensive solar cooker that made locally using the car-tire.The practical experiments were carried out under the local climatic conditions of Zagazig city, Egypt (Lat. 30 $35^{`} \mathrm{~N}$ and Lon. $30^{\circ} 31^{`}$ E) for comparing the thermal performance of an ordinary tire-solar cooker (without mirror) and another one provided with booster mirror. The obtained results revealed that, the boosted cooker with mirror achieved stagnation temperature of about 10\% more than the ordinary tire-cooker and faster by about 40 minutes with first figure of merit (F1) of 0.12 ${ }^{\circ} \mathrm{C} . \mathrm{m}^{2} / \mathrm{W}$, whereas the ordinary was $0.10^{\circ} \mathrm{C} . \mathrm{m}^{2} / \mathrm{W}$ at solar radiation 565 $\mathrm{W} / \mathrm{m}^{2}$. Also, by increasing the mass of water from 0.5 to $1.5 \mathrm{~kg}$ the maximum temperature of water decreased from 87 to $75{ }^{\circ} \mathrm{C}$ and from 93 to $84^{\circ} \mathrm{C}$ for the ordinary and the boosted tire-cooker, respectively. Also, the use of boosted cooker was achieved the boiling temperature $\left(\sim 90^{\circ} \mathrm{C}\right)$ for the water mass of 0.50 and $1 \mathrm{~kg}$ as 93 and $91{ }^{\circ} \mathrm{C}$, respectively but the ordinary cooker could not reach the boiling temperature at all masses of water under the same climate .The boosted cooker with mirror achieved higher utilizable efficiency (30.46\%) than the ordinary one by about $20 \%$ at the maximum water mass of $1.50 \mathrm{~kg}$ and this cooker with aperture area of $1 \mathrm{~m}^{2}$ can boil $1 \mathrm{~kg}$ of water in about 16 min at utilizable efficiency of about 26\%.Hence, the use the proposed boosted tire-solar cooker can achieve a good thermal performance from small aperture area.

Keywords: thermal performance, solar cooker, old car-tire, booster mirror, aperture area

\section{INTRODUCTION}

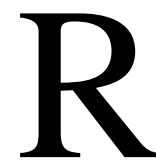
ecently, solar cooker was considered a very attractive method for trapping and exploiting the high intensity of solar radiation for that belong to the world sun belt like Egypt.

\footnotetext{
"Lecturer, Agric. Eng. Dept., Fac. of Agric., Zagazig Univ., Egypt
} 
Generally, the population at the rural and remote areas or even the isolated communities especially in the developing countries is fully depending on the conventional energy of cooking that may damage the environment. The energy required for cooking is supplied by noncommercial fuels like firewood, agricultural wastes, cow dung (Wentzel and Pouris, 2007). For that, the importance of the solar cooking is intruding as a green method for cooking in addition to reduce the money and efforts of bringing the conventional fuels from urban areas. Solar cookers come in many shapes and sizes, for example there are: box cookers, concentrating-type or reflector cookers, solar steam cookers, etc. This list could go on forever and designs vary, but all cookers trap heat in some form of insulated compartment (Saxena et al., 2011).An absorber tray first of all should have a remarkably high absorptivity in order to transfer maximum radiant energy to food in the cooking pot (Garg and prakash, 2004). Abu-Khader et al. (2011) concluded that the cookers at a fixed position had recorded thermal efficiencies ranging from $17 \%$ to a sharp peak of $41.2 \%$ at the maximum solar intensity of the day around 11-12 am with an average overall efficiency around 27.6\%. Narasimha and Subramanyam (2005) found that cooking vessel with central annular cavity on lugs performs much better than the conventional vessel kept on the floor of the cooker. Kurt, et al. (2008) used two different model solar box cookers, which are in rectangular and cylindrical geometries and performance parameters of each cooker were determined for $0.5,1$ and $1.5 \mathrm{~kg}$ of fresh water. The thermal efficiency increased from $12.7 \%$ to $36.98 \%$ for cylindrical and $9.85 \%$ to $28.25 \%$ for rectangular model, when the amount of water was increased from 0.5 to $1.5 \mathrm{~kg}$. The cylindrical model provided higher thermal efficiency and lower characteristic boiling time than the rectangular model. Cuce and Cuce (2013) reported that the cylindrical shaped cooking vessels made of aluminum or cooper and painted black should be preferred for a higher cooking efficiency. Hence, it is very important to re-use some municipal wastes such as, the expired car-tire to save the environment. Therefore, the objectives of the present study are: 
1. Utilization of the wasted car-tire to use as a simple and inexpensive solar cooker as a new method for exploiting the wasted car-tires and avoiding the environmental contamination.

2. Studying and comparing the thermal performance of the tire-solar cooker before and after adding the booster mirror especially in the low solar radiation season.

\section{MATERIALS AND METHODS}

The practical experiments of this study were performed at Faculty of Agriculture, Zagazig University, Egypt (Lat. $30^{\circ} 35^{`} \mathrm{~N}$, Long. $31^{\circ} 31^{\prime} \mathrm{E}$ ) to investigate the thermal performance of the tire-solar cooker

\section{Cooker description:}

The solar cooker - as shown in Fig.1- is mainly consists of old car-tire that made of rubber with total diameter of $580 \mathrm{~mm}$, height of $150 \mathrm{~mm}$ and aperture diameter of $360 \mathrm{~mm}$ that equal about $0.10 \mathrm{~m}^{2}$. The absorber container was made of $2 \mathrm{~mm}$ of aluminum sheet in a cylindrical shape with inner diameter of $355 \mathrm{~mm}$ and about $149 \mathrm{~mm}$ in depth. The inner surface of the absorber was painted with a black matt paint. The outer bottom of the absorber as well as the gap between the inner surface of the tire and the outer surface of the absorber was packed with a compact layer of glass wool as a thermal insulator Actually, two similar car-tire solar cookers were used in this study but one of them was provided with a single booster mirror that has $500 \mathrm{~mm}$ in length and $350 \mathrm{~mm}$ in width. A single tempered glass sheet with geometric dimension of $500 \times 500 \times 5 \mathrm{~mm}$ was used as cover of the cooker. The booster mirror was oriented for tracking the sun every 15 min, as shown in Fig(2). In all experiments of this study, an ordinary central annular cavity cooking pot was used. The pot has diameters of $245 \mathrm{~mm}$ at top $150 \mathrm{~mm}$ at bottom and depth of 85 $\mathrm{mm}$

\section{- The experiment procedures:}

The ordinary and booster mirror cookers were subjected to the sun rays during the period between 9 to 14/11/2015, where five thermocouples (Type K) connected to multi-channel datalogging thermometer (TENMARS Model: TM-747 DU) were used to measure the temperature of the absorber container $\left(\boldsymbol{T}_{p}\right)$ within the ordinary $\left(\boldsymbol{T}_{\boldsymbol{p} o}\right)$ and booster-mirror 
$\left(\boldsymbol{T}_{p m}\right)$ cooker, enclosure air $\left(\boldsymbol{T}_{\boldsymbol{e}}\right)$, the inner surface of the glass $\left(\boldsymbol{T}_{g i}\right)$, in addition to the temperature of the water $\left(\boldsymbol{T}_{w}\right)$ inside the pot by passing a thermocouple through a sealed hole at top of the pot's cover.

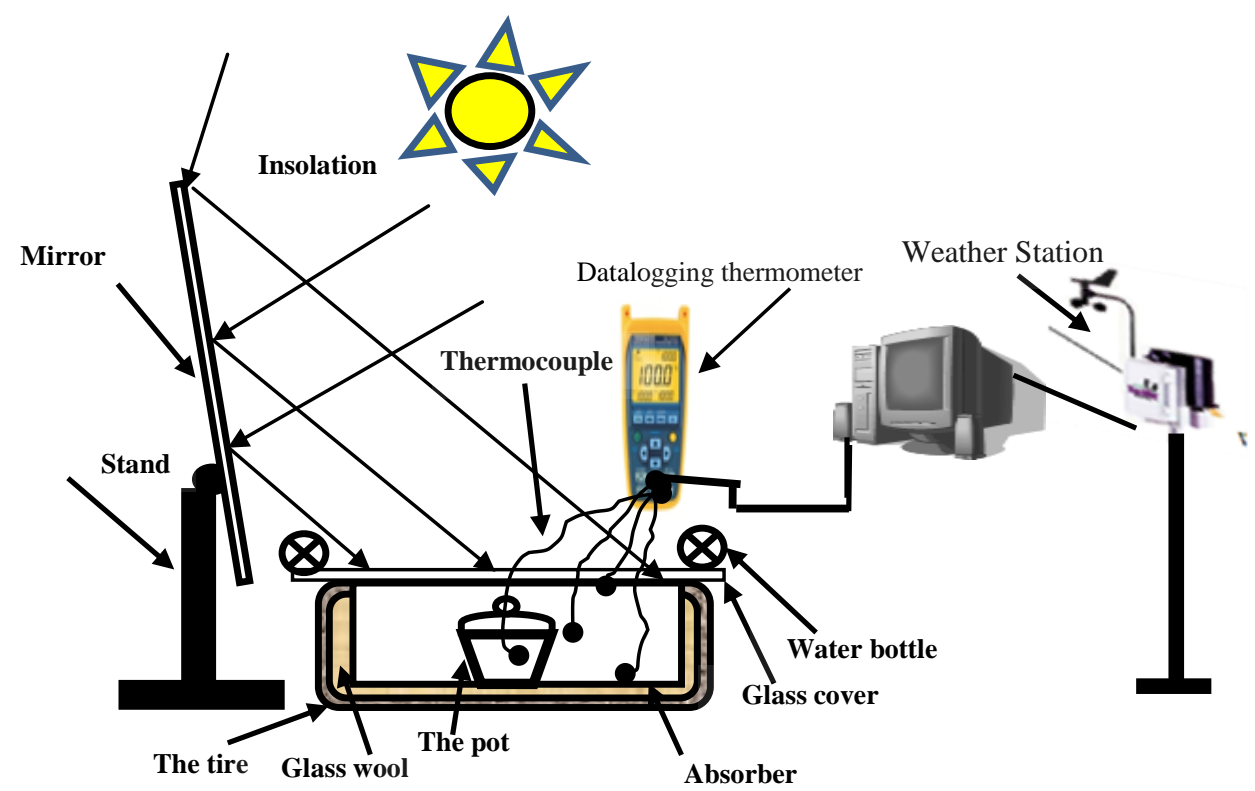

Fig.(1): The experimental setup

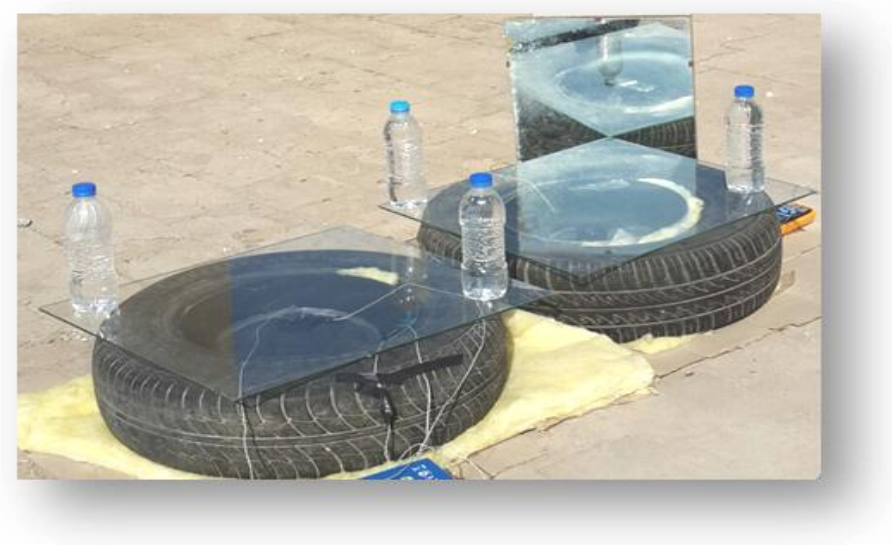

Fig. (2): View of the tire-solar cookers

A weather station (Watchdog, model 900 ET) was used to measure wind speed $(0-108 \mathrm{~km} / \mathrm{h})$, ambient temperature $\left(\boldsymbol{T}_{\boldsymbol{a}}\right)\left(-30: 100^{\circ} \mathrm{C}\right)$ and solar insolation $\left(H_{s}\right)\left(1-1250 \mathrm{~W} / \mathrm{m}^{2}\right)$. The whole data were recorded each 10 
minutes. All the practical experiments were performed when the wind speed did not exceed $2.50 \mathrm{~m} / \mathrm{s}(9 \mathrm{~km} / \mathrm{h})$ (Funk, 2000).

\section{- The experiment measurement:}

The thermal performance analysis of the solar cooker can be determined by using the following indicators:

\section{1- The first figure of merit $\left(F_{1}\right)$ :}

It is a preference that represents the ratio between the optical efficiency $\left(\eta_{o}\right)$ and the total heat losses factor $\left(U_{L}\right)$, where the high optical efficiency and low total heat losses factor are desirable. This figure can be obtained by conducting the stagnation temperature test. In this test the solar cooker is subjected to the sun in the clear sky day without pot (no load) in period from 10:00 am to $14: 00 \mathrm{pm}$. Just the absorber within the solar cooker to be constant, the $F_{1}$ can be determined by using the following relation given by ( Mullick, et al.1987):

$$
F_{1}=\frac{\eta_{o}}{U_{L}}=\frac{T_{P s}-T_{a s}}{H s}
$$

Where $F_{1}$ is the first figure of merit $\left({ }^{\circ} \mathrm{C} \cdot \mathrm{m}^{2} / \mathrm{W}\right)$, $\eta o$ is the optical efficiency (\%), $U_{L}$ is the overall heat loss factor $\left(\mathrm{W} /{ }^{\circ} \mathrm{C} . \mathrm{m}^{2}\right), T p s$ is the absorber plate temperature $\left({ }^{\circ} \mathrm{C}\right)$, Tas is the ambient temperature $\left({ }^{\circ} \mathrm{C}\right)$, and $H s$ is the insolation on a horizontal surface $\left(\mathrm{W} / \mathrm{m}^{2}\right)$ at the time when the absorber temperature stagnated.

2- The utilizable efficiency of cooker $\left(\eta_{u}\right)$, specific boiling time $\left(t_{s}\right)$ and characteristic boiling time $\left(t_{c}\right)$ :

The overall utilizable efficiency, $\eta_{u}(\%)$ is an indicator to the amount of the utilized solar energy by the cooker, while the specific boiling time, $t_{s}$ $\left(\min . \mathrm{m}^{2} / \mathrm{kg}\right.$ ) is represents the time required to boil $1 \mathrm{~kg}$ of water using a solar cooker of $1 \mathrm{~m}^{2}$ aperture area and the characteristic boiling time, $t_{c}$ $\left(\min . \mathrm{m}^{2} / \mathrm{kg}\right.$ ) may be used as a parameter for making comparisons between various solar cooker designs under different insolation conditions

$$
\begin{gathered}
\eta_{u}=\frac{(M C)_{w}\left(T_{w}-T_{a}\right)}{\bar{I}_{s} \cdot A_{p} \cdot \Delta t} \\
t_{s}=\frac{\Delta t A_{p}}{M} \cdot t_{c}=\frac{t_{s} \bar{I}_{s}}{I_{s}^{*}}
\end{gathered}
$$


Where $M, C$ are mass $(\mathrm{kg})$ and specific heat of water $\left(\mathrm{J} / \mathrm{kg} .{ }^{\circ} \mathrm{C}\right), T_{w}$ is the maximum temperature of the water load $\left({ }^{\circ} \mathrm{C}\right)$ and $T_{a}$ is the corresponding ambient temperature $\left({ }^{\circ} \mathrm{C}\right) . \Delta t$ is the time required to achieve at $T_{w}(\mathrm{~s}), A_{p}$ is the aperture area $\left(\mathrm{m}^{2}\right), \bar{I}_{s}$ is the average solar radiation for the time period $\Delta t\left(\mathrm{~W} / \mathrm{m}^{2}\right)$ and ${ }^{*}$ Is is the reference average solar intensity, i.e. 900 $\mathrm{W} / \mathrm{m}^{2}$.

\section{RESULTS AND DISCUSSION}

\section{1-The stagnation temperature test for the first figure of merit $(F 1)$}

The higher values of the first figure of merit $(F 1)$ would indicate better cooker performance. In this test, the both types of the tire-solar cooker, (the ordinary and that provided with the booster mirror) were subjected to the sun radiation through the period extended from 10:00 to 14:00 (Funk,2000) without load until the interior parts of the cookers attained their stagnated temperature. Fig.(3) illustrate that, the maximum temperature of the absorber for the ordinary $\left(T_{p o}\right)$ and boosted tire-solar cooker $\left(T_{p m}\right)$ were about $93^{\circ} \mathrm{C}$ at $13: 20$ and $99^{\circ} \mathrm{C}$ at $12: 40$ respectively.

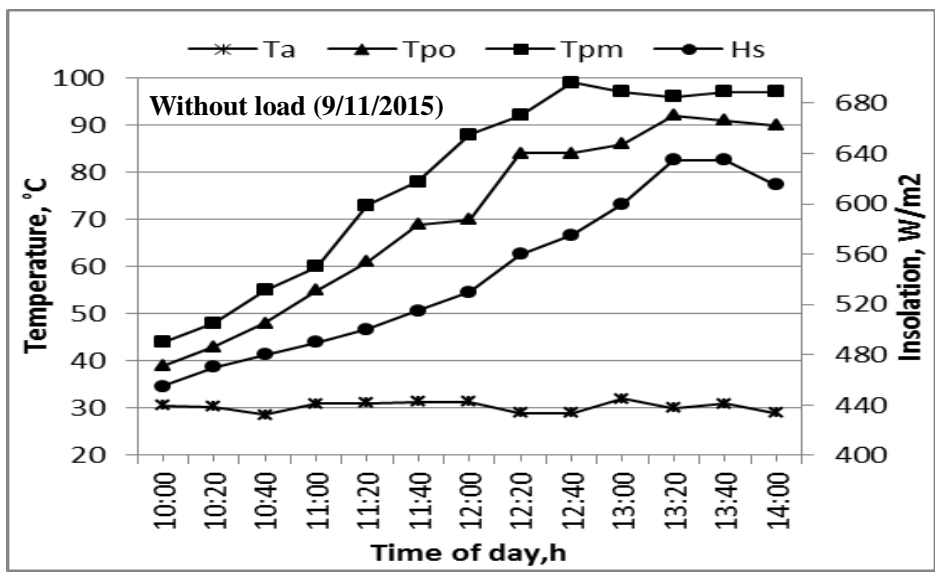

Fig.(3): The variation of insolation, temperatures of ambient, the absorber for ordinary and the boosted tire-solar cooker during the stagnation test.

Hence, the boosted cooker achieved a higher temperature than the ordinary one at insolation $\left(H_{s}\right)$ of $565 \mathrm{~W} / \mathrm{m}^{2}$ and ambient temperature of $\left(T_{a}\right) 30^{\circ} \mathrm{C}$ and reached its stagnated temperature earlier by about 40 
minutes and the declination of the temperature after stagnation was very slightly than the ordinary cooker. This can be due to the tracked booster mirror is working on gathering and entering considerable amount of radiation towards the cooker's cavity all the time in addition to the insulator and the tire rubber contributed in preventing the heat losses. The F1 was calculated to be 0.10 and $0.12{ }^{\circ} \mathrm{C} . \mathrm{m}^{2} / \mathrm{W}$ for the ordinary and boosted tire solar cooker, respectively. Since, the $F 1$ value for the boosted tire-cooker is higher than the lower limit of $\left(F 1 \geq 0.12^{\circ} \mathrm{C} \cdot \mathrm{m}^{2} / \mathrm{W}\right)$ that declared by (Mullick, et al.1987), so this cooker is efficient and can be classified as A-Grade cooker as suggested by (Mullick, et al.1996), whereas the ordinary one is classified as B-Grade.

\section{2- The temperature variation during heating up different masses of water}

In this study, the behavior of the temperatures for either the ordinary tiresolar cooker and the boosted one by mirror were recorded during heating up the pot (Full load) that filled with different water's masses $\left(M_{f}\right)$ of $0.50,1.00$ and $1.50 \mathrm{~kg}$ in period from 10 to $14 / 11 / 2015$, where the two cookers were kept in the sunshine and clear sky conditions from 9:00 to 14:00 during all the consecutive test days. The temperatures of the absorber $\left(T_{p}\right)$, enclosure air $\left(T_{e}\right)$, the inner surface of glass $\left(T_{g i}\right)$, water $\left(T_{w}\right)$, ambient $\left(T_{a}\right)$, in addition to the solar insolation $\left(H_{s}\right)$ were recorded at 20 min intervals, as shown in Figs. $(4,5)$.As a general trend in all consecutive test days, it was found that, the temperatures of the absorber $\left(T_{p}\right)$ and the enclosure air $\left(T_{e}\right)$ were higher than the temperature of water $\left(T_{w}\right)$ at the forenoon from 9:00 to 11:40 for the ordinary cooker, whereas this period was shorter (9:00 to 11:20) by about $20 \mathrm{~min}$ for the boosted cooker ,this is because the booster mirror reflects more solar radiation into the pot's body directly. But the contrarily was occurred at afternoon where the temperature of water $\left(T_{w}\right)$ tends to increase rapidly till its maximum temperature. From Figs. $(4,5)$, it is clear that, the value of the maximum temperature of water decreased by increasing the mass of water $\left(M_{f}\right)$ from 0.5 to $1.50 \mathrm{~kg}$ and took relatively long time to reach, because the water heat capacity increases as the mass increased. 
The ordinary tire-solar cooker
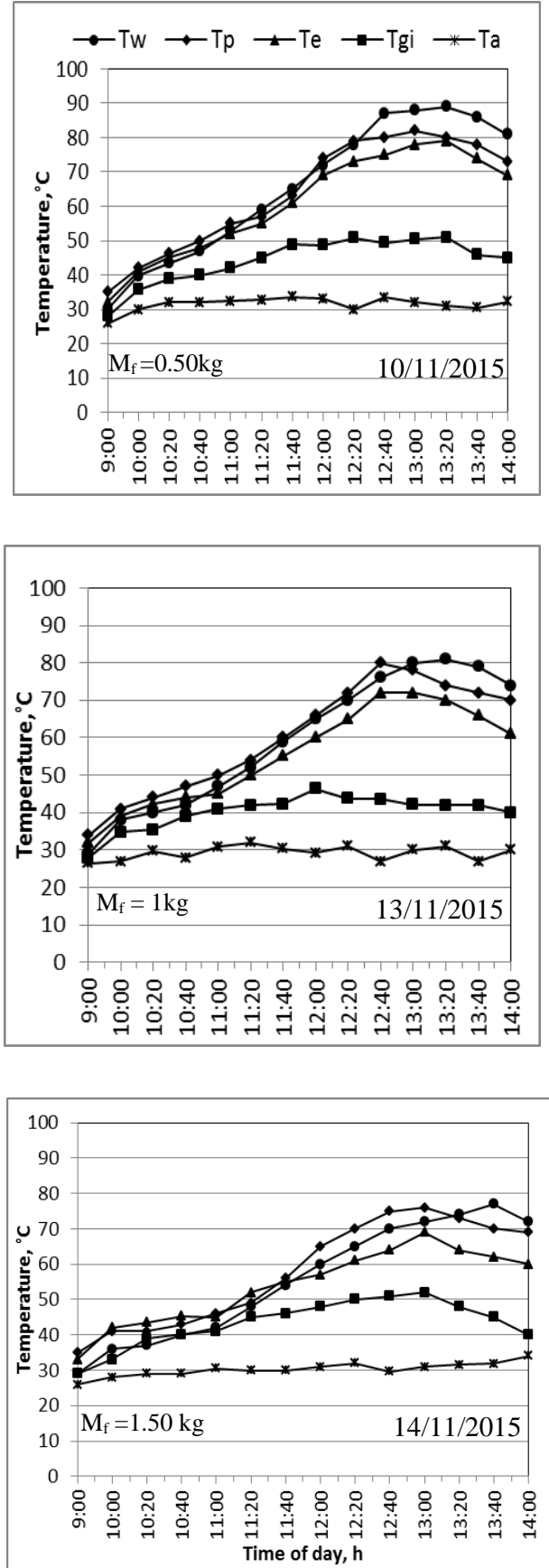

Fig.(4): The temperature variation Fig.(5): The temperature variation for the ordinary cooker at different water loads.
The tire-solar cooker with booster mirror
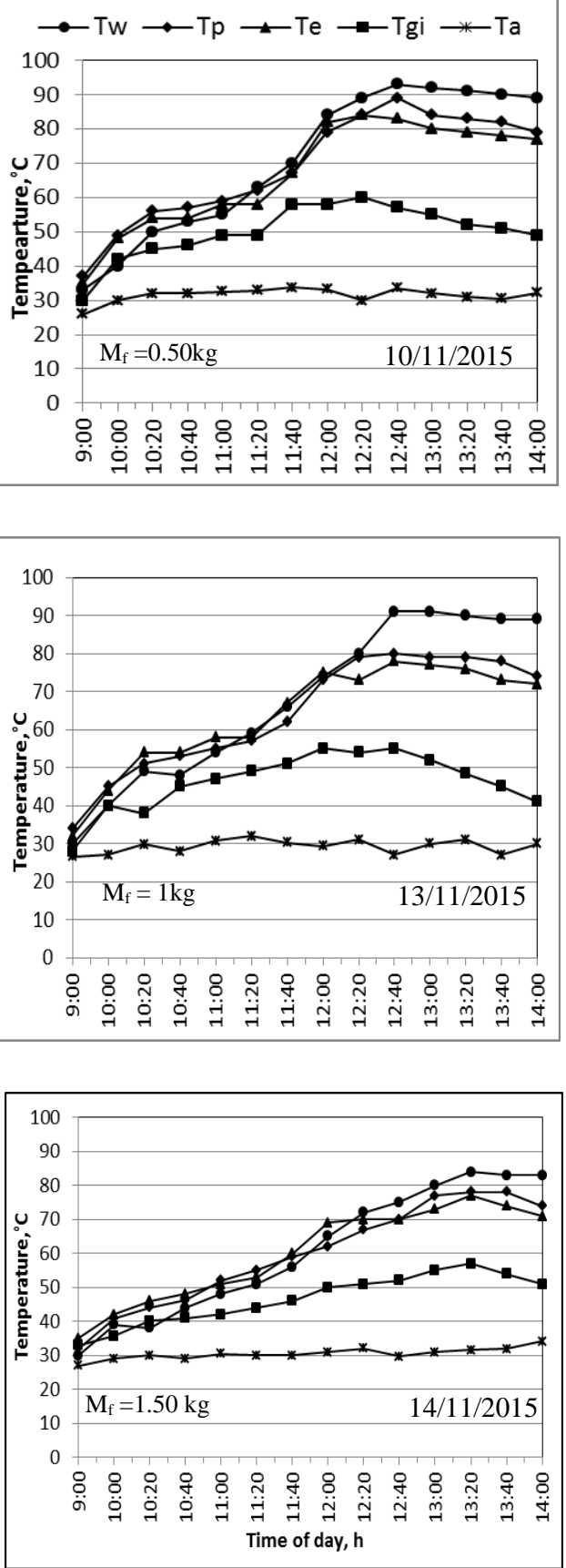

for the boosted cooker with mirror at different water loads. 
On the other hand, the temperature of the inner surface of glass $\left(T_{g i}\right)$ was very close to the enclosure air at forenoon, but at the noon and afternoon periods it tends to decrease slightly as a result of raising up the rate of heat transfer from the absorber and enclosure air to water. The results showed that, by increasing the mass of water from 0.5 to $1.5 \mathrm{~kg}$ the maximum temperature of water $\left(T_{w}\right)$ decreased from 87 to $75^{\circ} \mathrm{C}(13.8 \%)$ and from 93 to $84^{\circ} \mathrm{C}(9.6 \%)$ for the ordinary and the boosted tire-cooker, respectively. From Figs. $(4,5)$, it is clear that the use of the tire-cooker provided with booster mirror was achieved the boiling temperature $\left(\sim 90^{\circ} \mathrm{C}\right.$ as mentioned by Kurt et al.,2008) for the water mass of 0.50 and $1 \mathrm{~kg}$ as 93 and $91{ }^{\circ} \mathrm{C}$, respectively. This may be considered as good thermal performance for the boosted cooker. On the other hand, the ordinary tire-cooker could not reach the boiling phase at all masses of water under the same climatic conditions.

\section{3- The effect of water mass on the utilizable efficiency $\left(\eta_{u}\right)$, specific boiling time $\left(t_{s}\right)$ and characteristic boiling time $\left(t_{c}\right)$}

The values variation of the utilizable efficiency $\left(\eta_{u}\right)$, specific $\left(t_{s}\right)$ and characteristics boiling times $\left(t_{c}\right)$ for the ordinary solar-solar cooker and that provided with booster mirror using different loads (masses) of water was recorded in period from 10 to 14/11/2015 and plotted in Fig.(6). Concerning to the utilizable efficiency for the ordinary $\left(\boldsymbol{\eta}_{\boldsymbol{u}}\right)_{\mathrm{o}}$ and the boosted tire-solar cooker $\left(\boldsymbol{\eta}_{\boldsymbol{u}}\right)_{m}$, it is very clear from the obtained results that, the value of utilizable efficiency was increased by increasing the mass of water. The obtained data show that, the efficiency increased rapidly from 11.92 to $21.04 \%$ and from 14.80 to $26.33 \%$ by increasing the water mass from 0.50 to $1.00 \mathrm{~kg}$ for the ordinary and boosted tire-solar cooker, respectively. But, increasing water mass to $1.50 \mathrm{~kg}$ the utilizable efficiency increased slightly to be 24.17 and $30.24 \%$ for the ordinary and boosted tire-solar cooker, respectively. This because the high heat capacity of the high mass of water can be led to slow down the cooking rate. Generally, the tire-solar cooker provided with booster mirror achieved a higher utilizable efficiency than the ordinary one by about $20 \%$ at the maximum water mass of $1.50 \mathrm{~kg}$ during the days of tests. Fig. (6) illustrate that, the specific boiling time $\left(t_{s}\right)$ and characteristic boiling time $\left(t_{c}\right)$ decreased by increasing mass of water. The high value of the 
utilizable efficiency and low characteristic boiling time is very desirable, because it is an important indicator for the cooking speed. As displayed in Fig.(6), the boosted tire-cooker with aperture area of $1 \mathrm{~m}^{2}$ can boil $1 \mathrm{~kg}$ of water in about $16 \mathrm{~min}$ at utilizable efficiency of about $26 \%$. Hence, it is obvious that, the use the tire-solar cooker provided with booster mirror was achieved a high thermal performance from small aperture area at low solar radiation period

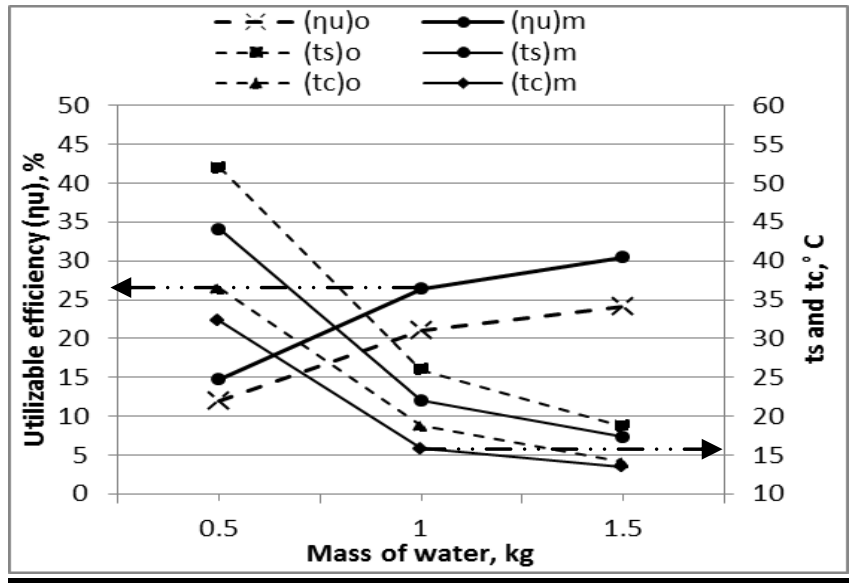

Fig. (6): The variation of the utilizable efficiency $\left(\eta_{u}\right.$ ), specific boiling time $\left(t_{s}\right)$ and characteristic boiling time $\left(t_{c}\right)$ for the ordinary and boosted tire-cooker at different masses of water.

\section{CONCLUSION}

The results show that, the tire-solar cooker provided with mirror achieved stagnation temperature of $10 \%$ more than the ordinary tire-cooker and faster by about 40 minutes. The first figure of merit was calculated to be 0.10 and 0.12 for the ordinary and boosted tire-solar cooker, respectively. Additionally, by increasing the mass of water from 0.5 to $1.5 \mathrm{~kg}$ the maximum temperature of water decreased from 87 to $75^{\circ} \mathrm{C}$ and from 93 to $84^{\circ} \mathrm{C}$ for the ordinary and the boosted tire-cooker, respectively. The boosted cooker with mirror achieved higher utilizable efficiency $(30.46 \%)$ than the ordinary one by about $20 \%$ at the maximum water mass of 1.50 $\mathrm{kg}$ and this cooker with aperture area of $1 \mathrm{~m}^{2}$ can boil $1 \mathrm{~kg}$ of water in about $16 \mathrm{~min}$ at utilizable efficiency of about $26 \%$. Finally, it is recommended to use the boosted tire-solar cooker to achieve a good thermal performance from small aperture area. 
PROCESS ENGINEERING

\section{REFERENCES}

Abu-Khader, M.; M. Abu Hilal; S. Abdallah and O. Badran (2011) Evaluating thermal performance of solar cookers under Jordanian climate. Jordan Journal of Mechanical and Industrial Engineering, 5(1):107-112

Cuce, E. and P. M. Cuce (2013) A comprehensive review on solar cookers. Applied Energy. 102 : 1399-1421.

Funk, P.A. (2000) Evaluating the international standard procedure for testing solar cookers and reporting performance. Solar Energy, 68(1): $1-7$.

Garg, H.P. and J. Prakash (2004) Solar energy fundamentals and applications. Tata McGraw Hill Publications.

Kurt, H.; E. Deniz and Z. Recebli (2008) An investigation into the effects of box geometries on the thermal performance of solar cookers. Int J Green Energy, 25(6):508-519.

Mullick, S. C.; T.C. Kandpal, and S. Kumar (1996) Testing of boxtype solar cooker: second figure of merit F2 and its variation with load and number of pots. Solar Energy, 57(5): 409- 413.

Mullick, S.C.; T.C. Kandpal and A.K. Saxena (1987) Thermal test procedure for box-type solar cookers. Solar Energy, 39(4):353-60.

Narasimha Rao, A.V. and S. Subramanyam (2005) Solar cookers part II: cooking vessel with central annular cavity. Solar Energy, 78:19-22.

Olwi, I. A. and A.M.A. Khalifa (1993) Numerical modeling and experimental testing of a solar grill. Journal of Solar Energy Engineering, 115(2):5-10.

Saxena, A.; S.P. Varun and G. Srivastav (2011) A thermodynamic review on solar box type cookers.Renewable and Sustainable Energy Reviews, 15: 3301-3318.

Wentzel M. and A. Pouris (2007) The development impact of solar cookers: a review of solar cooking impact research in South Africa. Energy Policy, 35: 1909-1919. 


\section{PROCESS ENGINEERING}

\section{الملخص العربي \\ الأداء الحراري لطباخ شمسي تجريبي مصنوع من إطار السيارات \\ حنان محمد سعد الاين الثال"}

الهدف من هذة الدراسة هو تقييم الأداء الحراري لطباخ شمسي بسيط، رخيص الثمن ومصنوع محليً من خلال إستغلال إطار السيارات. جميع التجارب العملية إجريت تحت الظروف الجوية

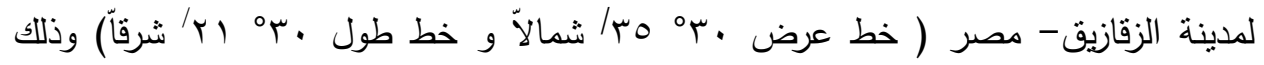
لمقارنة الأداء الحراري لطباخ شمسي مصنوع من إطار السيارات العادي (غير مزود بمرآ عاكسة) وأخر معزز بمرآه. أشنارت النتائج أن الطباخ المعزز بمرآه حقق درجة حرارة ركود أكثر بحوالي · ( \% وأسرع بحوالي · ع دقيقة مقارنة بالطباخ العادي، كذلك حقق الطباخ المعزز بمرآ

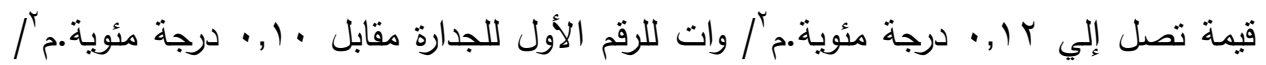
وات للطباخ العادي تحت إثعاع شمسي مقداره

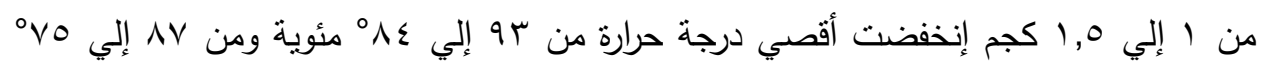

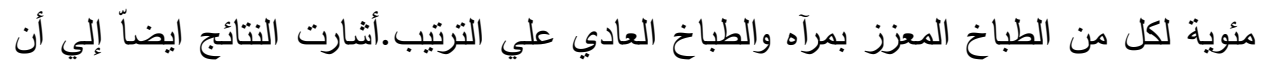

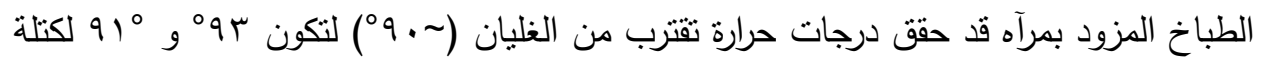
الماء •0, • و ا كجم علي الترتيب بينما لم يحقق الطباخ العادي درجة الغليان لأي من كتل الماء تحت نفس الظروف الجوية. كذلك وجد أن الطباخ المعزز بمرآه قد حقق أعلي كفاء للأستخدام تصل إلي ج؟,. •r\% و بزيادة قدرها حوالي .r\% مقارنة بالطباخ الثمسي الغير مزود بمرآه، حيث بمكن للطباخ المعزز بمرآه أن يغلي ا كجم من الماء في 17 دقيقة وبكفاءة إستخدام تصل إلي ؟r\% . ومن هنا فإن إستخدام الطباخ الشمسي الطباخ الشمسي المعزز بمرآ المقترح قد حقق أداء حراري جيد من أقل مساحة للطباخ.

* مدرس الهندسة الزراعية ـ كلية الزراعة ـ جامعة الزقازيق - مصر. 